\title{
Control of Postharvest Decay of Apple Fruit with Candida saitoana and Induction of Defense Responses
}

\author{
Ahmed El Ghaouth, Charles L. Wilson, and Michael Wisniewski
}

First author: Universite De Nouakchott, Faculte des Sciences et Techniques, Nouakchott, Mauritania, B.P. 5026; and second and third authors: U.S. Department of Agriculture-Agricultural Research Service, Appalachian Fruit Research Station, 45 Wiltshire Road, Kearneysville, WV 25430.

Accepted for publication 1 October 2002.

\begin{abstract}
El Ghaouth, A., Wilson, C. L., and Wisniewski, M. 2003. Control of postharvest decay of apple fruit with Candida saitoana and induction of defense responses. Phytopathology 93:344-348.

The ability of Candida saitoana to induce systemic resistance in apple fruit against Botrytis cinerea was investigated. To separate the antagonistic activity of $C$. saitoana from its ability to induce resistance, the antagonist and the pathogen were applied in spatially separated wounds. In fresh apples, $C$. saitoana applied 0 or $24 \mathrm{~h}$ before inoculation with $B$. cinerea showed no effect on lesion development caused by $B$. cinerea.

compared with wounding. C. saitoana had no effect on lesion development on stored apples, regardless of the lag period between yeast treatment and inoculation with $B$. cinerea. In addition to inducing systemic resistance, $C$. saitoana increased chitinase and $\beta-1,3$-glucanase activities with a higher accumulation in fresh than in stored apples. In fresh apples, the onset of systemic resistance to $B$. cinerea coincided with the increase in chitinase and $\beta$-1,3-glucanase activity in systemically protected tissue. These studies show that $C$. saitoana is capable of inducing systemic resistance in apple fruit and indirectly suggest that antifungal hydrolases are involved in the observed systemic protection.
\end{abstract} When applied 48 to $72 \mathrm{~h}$ preinoculation with $B$. cinerea, however, $C$. saitoana reduced lesion diameter by more than 50 and $70 \%$, respectively,

Recently, several antagonistic microorganisms have been shown to effectively control a number of postharvest pathogens on a variety of harvested commodities $(3-5,7,10,23)$. The mode of action of antagonistic yeasts, however, has not been fully elucidated. The biocontrol activity of antagonistic yeasts has been shown to depend on the inoculum density of the yeast and can be diminished by the addition of nutrients to the wound site $(4,5,10)$. These observations, together with the fact that yeasts are capable of attaching tenaciously to fungal cell walls $(7,25)$, suggest the involvement of nutrient and space competition as well as direct parasitism in the mode of action of antagonistic yeasts.

Additional modes of action, such as induced resistance, have been suggested $(5,7)$. In recent years, considerable attention has been placed on induced resistance as an important manageable form of plant protection, and several active microbial and chemical elicitors have been identified and shown to protect a variety of plants $(8,11-13,17,19,21,22)$. Upon infection or treatment with elicitors, plant tissue often reacts by activating a highly coordinated biochemical and structural defense system that helps ward off the spread of pathogens $(11,12,17,21)$. Induced defense reactions can be restricted to tissue close to the site of the stimulus or can be expressed systemically throughout the tissue. Site-restricted biochemical and structural defense responses include the rapid death of cells (referred to as the hypersensitive response), the reinforcement of the cell wall by deposition of lignin, callose, and hydroxyproline-rich glycoproteins, and the accumulation of antimicrobial secondary metabolites called phytoalexins $(8,11,12,21)$, whereas host defense responses expressed systemically involve the synthesis and accumulation of antifungal glucanohydrolases

Corresponding author: M. Wisniewski; E-mail address: mwisniew@afrs.ars.usda.gov

Publication no. P-2003-0120-02R

This article is in the public domain and not copyrightable. It may be freely reprinted with customary crediting of the source. The American Phytopathological Society, 2003.
Additional keywords: antagonistic yeast, disease resistance, gray mold. such as chitinase, chitosanase, and $\beta$-1,3-glucanase $(11,17,21,22)$. In several plant-pathogen interactions, the induction and accumulation of chitinase and $\beta$-1,3-glucanase is often correlated with the onset of induced resistance $(8,11-13,17,21,22)$.

Although harvested produce also possess inducible defensive responses, this potential has not received the attention it deserves. Activating biochemical defense responses in harvested tissue through prestorage treatment with UV light $(15,16)$ and antagonistic yeasts $(5,7)$ suggests that intensification of defense mechanisms has potential in reducing postharvest decay. Antagonistic yeasts induce several defense responses including the accumulation of the phytoalexin, scoparone, in citrus peel $(2,16)$, the deposition of structural barriers in apple fruit (7), and an increase in $\beta$ 1,3-glucanase, chitinase, and peroxidase activities in apple fruit (9). In these studies, the implication of induced resistance in the local protection provided by antagonistic yeasts was not clearly demonstrated because no attempt was made to separate the antagonistic activity of the yeasts from the fruit-mediated disease suppression.

This study was undertaken to determine whether treatment of apple fruit with Candida saitoana Nakasa \& Suzuki induces systemic resistance to Botrytis cinerea Pers.:Fr. and to determine the temporal and spatial induction patterns of chitinase and $\beta-1,3-$ glucanase in apple fruit treated with $C$. saitoana.

\section{MATERIALS AND METHODS}

Reagents, microorganisms, and fruit material. $C$. saitoana was streaked on nutrient yeast dextrose agar plates and incubated for $48 \mathrm{~h}$ at $24^{\circ} \mathrm{C}$. Nutrient yeast dextrose broth cultures, $50 \mathrm{ml}$ in a 125-ml Erlenmeyer flask, were started with approximately $108 \mathrm{CFU}$ of yeast. Cultures were incubated for $48 \mathrm{~h}$ at $24^{\circ} \mathrm{C}$ on a rotary shaker set at $200 \mathrm{rpm}$ (7). Yeast cells were pelleted by centrifugation with a Sorval RC-58 centrifuge (Dupont Instruments, Wilmington, DE) at $3,000 \times g$ for $20 \mathrm{~min}$, resuspended in 
sterile distilled water, and centrifuged again. The resulting pellets were dispersed in sterile distilled water, yeast counts were determined with a hemacytometer, and the concentration of the yeast was adjusted with sterile water to obtain $10^{8} \mathrm{CFU} \mathrm{ml}^{-1}$.

$B$. cinerea was isolated from infected fruit and maintained on potato dextrose agar (PDA; Difco Laboratories, Detroit). Conidia of $B$. cinerea were obtained from 2-week-old PDA cultures of $B$. cinerea incubated at $27^{\circ} \mathrm{C}$ in the dark $(7,9)$. Conidial suspensions of $B$. cinerea were prepared by flooding the culture plates with $10 \mathrm{ml}$ of sterile distilled water containing $0.1 \%$ (vol/vol) Tween 80. Spore counts were determined with a hemacytometer, and spore concentrations were adjusted with sterile distilled water to obtain $10^{5}$ spores per $\mathrm{ml}$.

Tree-ripe apples (Malus domestica Borkh. cv. Red Delicious) were hand-picked at harvest maturity at the Appalachian Fruit Research Station, Kearneysville, WV. Fruit were sorted to remove any with apparent injuries or infections and stored at $4^{\circ} \mathrm{C}$ under high humidity (95\% relative humidity $[\mathrm{RH}]$ ) for 1 week to 5 months before being used in biocontrol tests.

Induced disease resistance by $\boldsymbol{C}$. saitoana. Experiment 1 . Fresh apples (firmness $=72$ to 80 newtons $[\mathrm{N}]$ ) and stored apples (firmness $=31$ to $40 \mathrm{~N}$ ) were wounded individually at two different locations, approximately $2 \mathrm{~cm}$ apart, to ensure spatial separation between the antagonist, $C$. saitoana, and the pathogen $B$. cinerea. On each fruit, the initial wound ( $3 \mathrm{~mm}$ wide by $5 \mathrm{~mm}$ deep) was treated with $35 \mu \mathrm{l}$ of a yeast suspension at $10^{8} \mathrm{CFU} \mathrm{ml}{ }^{-1}$ or sterile water and, at various time intervals $(0,24,48$, and $72 \mathrm{~h})$ after treatment, superficial wounds (approximately $5 \mathrm{~mm}$ wide by $1 \mathrm{~mm}$ deep) were made with a razor blade and challenge-inoculated with $10 \mu \mathrm{l}$ of a spore suspension of $B$. cinerea at $10^{4}$ spores per $\mathrm{ml}$. Treated fruit and their water-treated controls were stored at $20^{\circ} \mathrm{C}$ under high humidity $(95 \% \mathrm{RH})$ in enclosed plastic trays $(7,9)$. For each treatment at each inoculation time interval, four replicates of 10 fruit were arranged in a randomized complete block design and the entire experiment was conducted twice. Fruit were evaluated daily for rot development and superficial wounds, challenged with B. cinerea, and those showing signs of contamination with antagonistic yeast were discarded at each inspection. Wounds contaminated with $C$. saitoana often appear white because excessive growth of the yeast at wound site (7). At the end of 7 days of storage, lesion diameters at the wound site were determined and tissue samples containing the superficial wounds were analyzed for contamination with $C$. saitoana. Tissue samples were removed with a 6-mm-diameter (no. 7) cork borer from four apples randomly selected from each treatment, homogenized in $5 \mathrm{ml}$ of sterile water, vortexed, dilution-plated in triplicate on yeast-maltose agar medium, and the plates were incubated at $24^{\circ} \mathrm{C}$.

The data from the two experiments were analyzed using analysis of variance (ANOVA). Homogeneity of variance for the two experiments was evaluated by Hartley's F-Max test at $P=0.05$ of the lesion diameters. If variance did not differ significantly, data from separate trials were combined and analyzed by ANOVA. Duncan's new multiple range test $(P=0.05)$ to separate means was applied to compare treatments.

Experiment 2. Fresh and stored apples were individually wounded and treated with a yeast suspension or sterile water as described previously. Nonwounded controls were treated with sterile distilled water. Treated fruits were stored at $20^{\circ} \mathrm{C}$ under high humidity $(95 \% \mathrm{RH})$ in enclosed plastic trays. For each treatment, four replicates of 10 fruit each were arranged in a randomized complete block design. The experiment was maintained for 1 week and conducted twice.

Tissue samples were collected at various time intervals $(0,12$, 24,48 , and $72 \mathrm{~h}$ ) after treatment from six fruit randomly selected from each treatment, two fruit from each of two replicates and one fruit from each of the two remaining replicates. From each fruit, tissue samples were removed with a 6-mm-diameter cork borer from both yeast and water-treated wounds and from healthy tissue
$2 \mathrm{~cm}$ from the edge of the yeast and water-treated wound. Samples were individually extracted in a prechilled mortar and pestle in 2 volumes (wt/vol) of $50 \mathrm{mM}$ sodium acetate buffer, $\mathrm{pH}$ 5.0. The homogenate was centrifuged at $4^{\circ} \mathrm{C}(15 \mathrm{~min}, 10,000 \times g)$ and the proteins in the supernatant were precipitated in $60 \%$ acetone (vol/vol) at $-20^{\circ} \mathrm{C}$. Following centrifugation $\left(12,000 \times g\right.$ at $4^{\circ} \mathrm{C}$ for $30 \mathrm{~min}$ ), the resulting pellet was washed twice with $60 \%$ acetone and reconstituted with $2 \mathrm{ml}$ of $50 \mathrm{mM}$ sodium acetate buffer ( $\mathrm{pH}$ 5.0). Protein concentrations were determined with a protein assay kit (Bio-Rad Laboratories, Hercules, CA).

Enzyme assays. Chitinase activity was assayed with a dyelabeled carboxymethylchitin according to the method described by Wirth and Wolf (24). Chitinase activity was measured by mixing $100 \mu \mathrm{l}$ of crude enzyme solution with $200 \mu \mathrm{l}$ of $2 \%$ dye-labeled carboxymethylchitin in $50 \mathrm{mM}$ sodium acetate buffer ( $\mathrm{pH} \mathrm{5.0)}$. After $2 \mathrm{~h}$ of incubation at $37^{\circ} \mathrm{C}$, the reaction was stopped by adding $100 \mu \mathrm{l}$ of $1.0 \mathrm{M} \mathrm{HCl}$, the reaction mixture was cooled and centrifuged, and the absorbance of the supernatant was measured at $550 \mathrm{~nm}$. Chitinase activity was calculated according to Wirth and Wolf (24) and was measured in international units (U) per microgram of total protein. One international unit was defined as the amount of enzyme required to catalyze the formation of $1 \mathrm{nmol}$ product per minute.

$\beta$-1,3-Glucanase was determined following the method of Abeles and Forrence (1). $\beta-1,3-$ Glucanase activity was assayed by incubating $62.5 \mu \mathrm{l}$ of enzyme preparation for at least $2 \mathrm{~h}$ at $40^{\circ} \mathrm{C}$ in $62.5 \mu \mathrm{l}$ of $4 \%$ laminarin. The reaction was terminated by heating the sample in boiling water for $5 \mathrm{~min}$ and the amount of reducing sugars was measured spectrophotometrically at $492 \mathrm{~nm}$ after reaction with $372 \mu \mathrm{l}$ of a dinitrosalicyclic reagent. Final activity values are expressed in nanokatal (nktal) per microgram of total protein. One nanokatal was defined as the enzyme activity catalyzing the formation of $1 \mathrm{nmol}$ glucose equivalents per second.

\section{RESULTS}

Induced resistance. $C$. saitoana applied in apple wounds, spatially separated from the site of challenge with $B$. cinerea, caused an induction of disease resistance that was markedly influenced by (i) the time lag between yeast treatment and inoculation with $B$. cinerea; and (ii) fruit stage of ripeness (Fig. $1 \mathrm{~A}$ and B). $C$. saitoana was effective in inducing disease resistance on fresh apples but not on stored apples. With fresh apples, $C$. saitoana applied either immediately or $24 \mathrm{~h}$ before inoculation with $B$. cinerea had no significant effect on lesion development caused by B. cinerea. When applied 48 or 72 h prior to inoculation with $B$. cinerea, however, $C$. saitoana was very effective in reducing lesion development and the level of reduction was significantly higher than that observed with wounding alone (Fig. 1A). Increasing time lapse between yeast treatment and inoculation from 48 to $72 \mathrm{~h}$ resulted in an increase in the reduction of lesion development. After 7 days of storage, C. saitoana applied 48 and $72 \mathrm{~h}$ before inoculation reduced lesion development on fresh apples by more than 50 and $70 \%$, respectively, compared with wounding alone (Fig. 1A). With fresh apples, wounding alone caused no significant reduction in lesion development compared with the control. On stored apples, $C$. saitoana showed no significant effect on lesion development, regardless of the lag period between yeast treatment and inoculation with B. cinerea (Fig. 1B). The levels of reduction obtained with $C$. saitoana were comparable to nonwounded and wounded controls. Analysis of tissue samples from superficial wounds of fresh and stored apples inoculated with $B$. cinerea and collected after 7 days of storage showed no sign of contamination with $C$. saitoana (data not shown).

Induction of antifungal hydrolases by $C$. saitoana. Analysis of the induction kinetics of chitinase and $\beta$-1,3-glucanase activity in wounds of fresh apples showed that the yeast treatment caused an increase in chitinase and $\beta$-1,3-glucanase levels starting $12 \mathrm{~h}$ 
after treatment, with the maximum accumulation occurring after $96 \mathrm{~h}$. At $48 \mathrm{~h}$ after yeast treatment, chitinase and $\beta$-1,3-glucanase activities in apple wounds were approximately twofold above that observed in the wounded control and the induction levels of these enzymes were maintained for up to $96 \mathrm{~h}$ after treatment (Fig. 2A and $B)$. An increase in chitinase and $\beta$-1,3-glucanase activity with time was also observed in wounded control fruit. Over $96 \mathrm{~h}$, chitinase activity increased in wounded fruit from a basal level of 0.24 to $0.67 \mathrm{U} / \mu \mathrm{g}$ of protein (Fig. $2 \mathrm{~A}$ ). In the same time period, $\beta$-1,3-glucanase activity increased from 23 to $73 \mathrm{nktal} / \mu \mathrm{g}$ of protein. In nonwounded control fruit, a comparatively small but detectable increase in chitinase and $\beta$-1,3-glucanase activity was observed.

In stored apples, the induction of chitinase and $\beta$-1,3-glucanase activities in response to yeast and wounding followed the same pattern as seen in fresh apples, except the extent of accumulation of chitinase and $\beta$-1,3-glucanase activities was markedly higher in fresh apples (Fig. 3A and B). Chitinase and $\beta$-1,3-glucanase activities in fresh apples treated with $C$. saitoana was approximately twofold higher than in stored apples throughout the time period monitored starting $24 \mathrm{~h}$ after treatment. With stored apples, the yeast treatment and wounding induced increased chitinase and $\beta$ 1,3-glucanase activity starting after a lag of $6 \mathrm{~h}$. The level of the increase of both enzymes appeared slightly higher in yeast-treated wounds than in controls (Fig. 3A and B). In nonwounded control fruit, a comparatively small but detectable increase in chitinase and $\beta$-1,3-glucanase activity was observed.

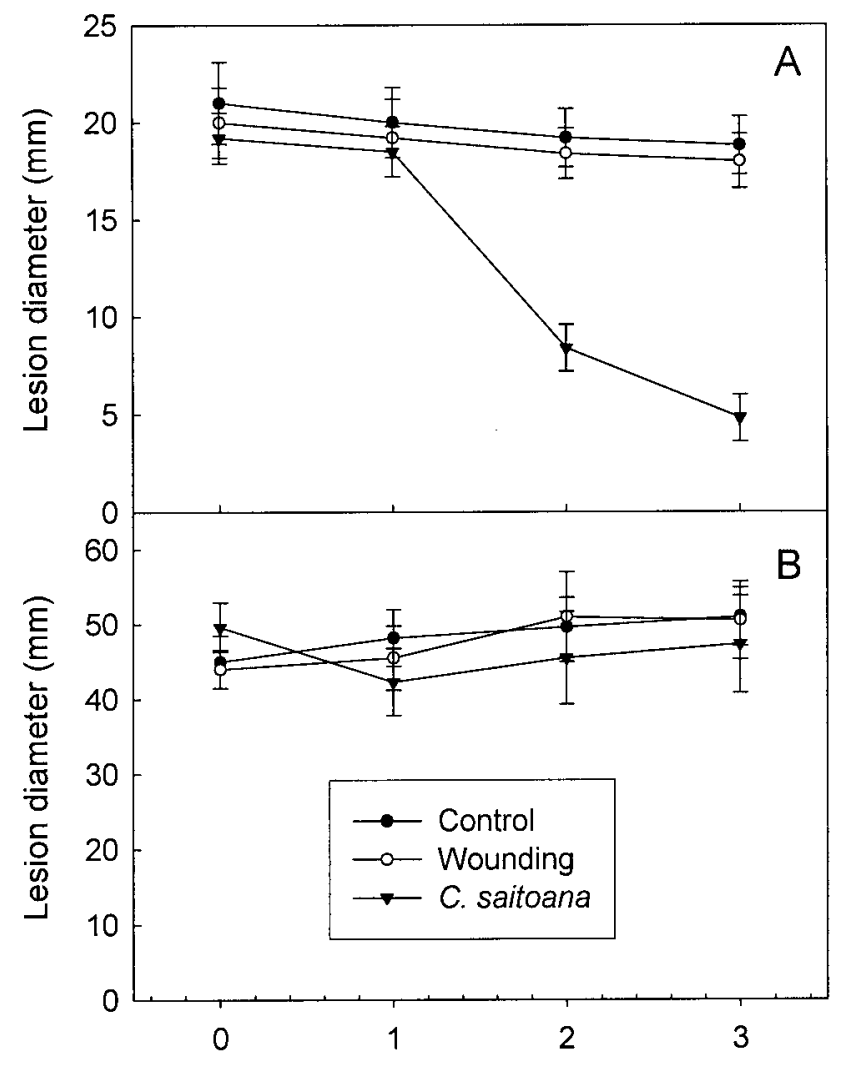

Time from treatment to inoculation (days)

Fig. 1. Effect of Candida saitoana on lesion development caused by Botrytis cinerea on A, fresh and $\mathbf{B}$, stored apples. Fresh and stored apples were individually wounded and fruit wounds were treated with $35 \mu \mathrm{l}$ of a yeast suspension at $10^{8} \mathrm{CFU} \mathrm{ml}-1$ or sterile water. Thereafter, on each fruit a superficial wound, $2 \mathrm{~cm}$ away from the edge of the initial wound, was made at various time intervals $(0,24,48$, and $72 \mathrm{~h})$ after treatment and challengeinoculated with $10 \mu \mathrm{l}$ of a spore suspension of $B$. cinerea at $10^{5}$ spores per $\mathrm{ml}$. Lesion diameter was based on four replicates of 10 fruit each and was determined after 7 days of storage at $20^{\circ} \mathrm{C}$.
In fresh apples, the increase of chitinase and $\beta$-1,3-glucanase activity by $C$. saitoana was not restricted to the treatment site. Analysis of the tissue area adjacent to yeast-treated wounds showed a gradual increase in chitinase and $\beta$-1,3-glucanase activity (Fig. 4A and B), but the overall increase remained lower than that observed in yeast-treated wounds (Fig. 2 versus Fig. 4). In tissue areas close to the yeast-treated wounds, chitinase and $\beta-1,3-$ glucanase activities increased markedly at 2 days after treatment and by 4 days was approximately twofold higher than the control levels. In wounded control fruit, the induction of chitinase and $\beta$ 1,3 -glucanase appeared mainly limited to the wound site. No apparent increase in chitinase and $\beta$-1,3-glucanase activities above the constitutive levels was detected in tissue area close to the wound site and the level of activity was comparable to the control (Fig. 4A and B). With stored apples, the induction of chitinase and $\beta$-1,3-glucanase activities by $C$. saitoana and wounding was mainly limited to the treatment site. No apparent change in chitinase and $\beta$-1,3-glucanase activities was detected in tissue areas adjacent to the treatment site (data not shown).

\section{DISCUSSION}

Induction of disease resistance following treatment with microbial and chemical inducers has been demonstrated in a number of

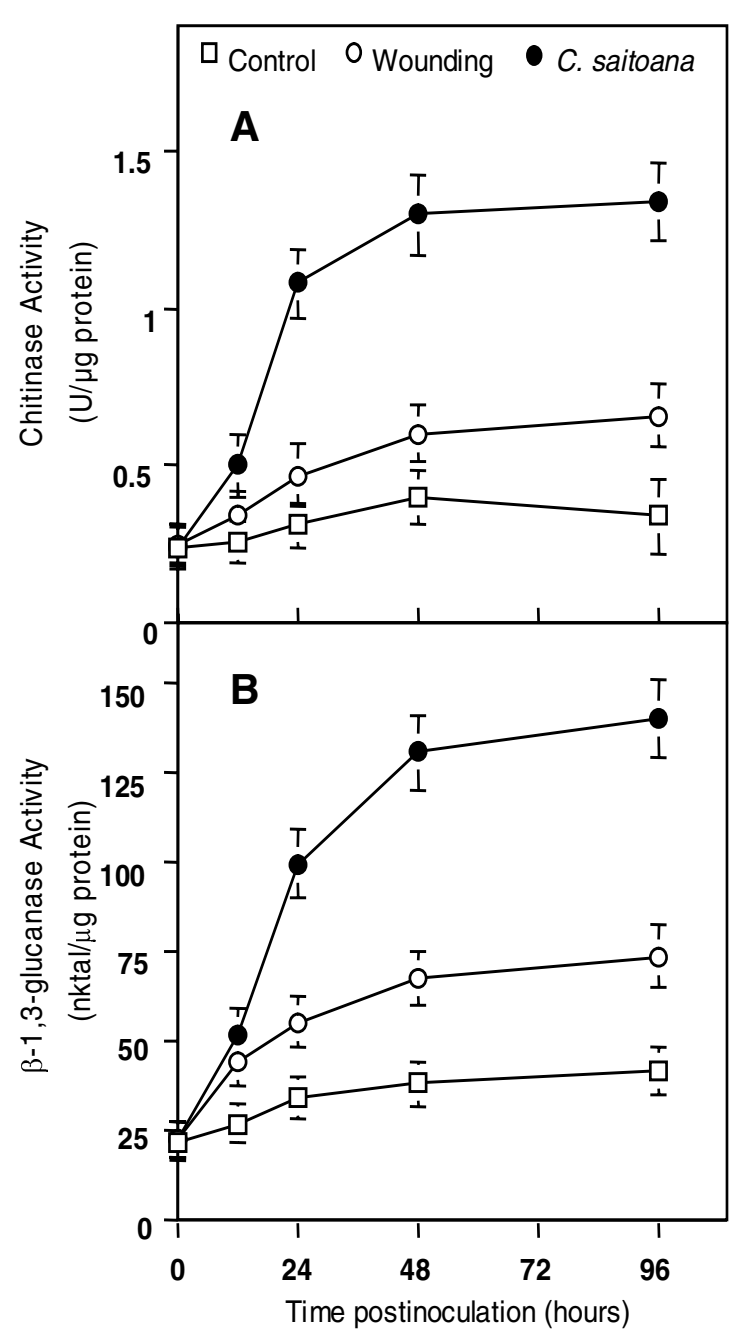

Fig. 2. Time course of changes in $\mathbf{A}$, chitinase and $\mathbf{B}, \beta-1,3$-glucanase activity in extracts from wounds of fresh apples treated with Candida saitoana (•) or sterile water $(O)$ and of nonwounded control fruit $(\square)$. Extracts were obtained 0, 12, 24, 48, and $96 \mathrm{~h}$ after treatment, and enzyme activities were determined. The figure is based on the data from a representative of two repeated experiments. Mean \pm SD. 
crops and provides protection against a wide range of pathogens (11-13,17,21,22). In harvested commodities, the induction of disease resistance by microbial antagonists has been inferred but not clearly established because other putative modes of action of the antagonist could not be ruled out. In this study, we show that the treatment of apple wounds with $C$. saitoana induced a resistance against $B$. cinerea that was expressed in tissues distant from the site where the yeast was applied.

This systemic protection developed gradually with time and was highly dependent on fruit stage of ripeness. In apples stored for 5 months, $C$. saitoana showed no effect on lesion development caused by $B$. cinerea, regardless of the lag period between yeast treatment and inoculation. In contrast, challenge inoculation of fresh apples with $B$. cinerea at different times following a yeast treatment showed that resistance occurred after $24 \mathrm{~h}$. When the antagonist and the pathogen however were simultaneously applied in spatially separated wounds, no apparent effect on lesion development was noted. This indicates the need for a lag period for the establishment of a resistance state and confirms earlier observations in other crops treated with microbial elicitors in which it took from 1 day to a few weeks for induced resistance to develop $(8,12,14)$. These observations, together with the fact that the antagonist and the pathogen were spatially separated during the

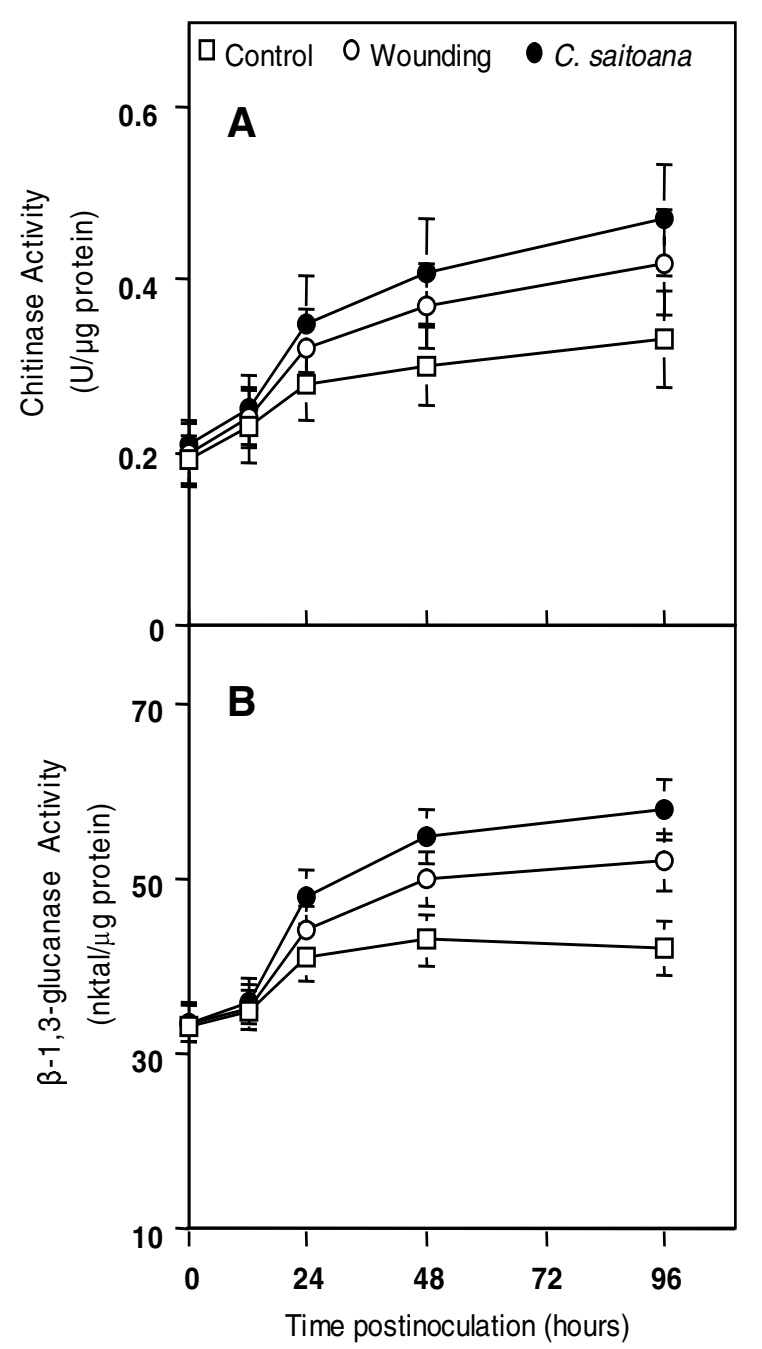

Fig. 3. Time course of changes in $\mathbf{A}$, chitinase and $\mathbf{B}, \beta-1,3$-glucanase activity in extracts from wounds of stored apples treated with Candida saitoana ( $\bullet$ ) or sterile water $(O)$ and of nonwounded control fruit $(\square)$. Extracts were obtained 0,12, 24, 48, and $96 \mathrm{~h}$ after treatment, and enzyme activities were determined. The figure is based on the data from a representative of two repeated experiments. Mean \pm SD. course of the experiments, strongly suggest that the observed protection is mediated through the induction of the host defense responses rather than due to the antagonistic activity of $C$. saitoana.

Along with the induction of a systemic protection in fresh apples, $C$. saitoana also caused a rapid accumulation of chitinase and $\beta$-1,3-glucanase activities locally in the treated wound site and systemically in tissues distant from the initial wound. The overall extent of the induction, however, was markedly higher at the site of the primary inoculation (initial wound) than in tissues distant from the wound. This is in agreement with previous reports characterizing the spatial induction of hydrolases in several plants species treated with elicitors $(8,19)$ and suggests the involvement of a systemic signal produced at the site of primary inoculation. The induction of chitinase and $\beta-1,3$-glucanase by $C$. saitoana appears to be dependent on fruit stage of ripeness, indicated by a greater accumulation of chitinase and $\beta$-1,3-glucanase in fresh apples than in stored apples where the induction was restricted to the wound site. This may explain in part the inability of the yeast to induce systemic resistance in stored apples.

The comparatively low accumulation of chitinase and $\beta-1,3-$ glucanase activity in stored apples may be due to a diminished ability of fruit tissues to respond to stress conditions such as yeast challenge. Because harvested commodities rely on their own re-

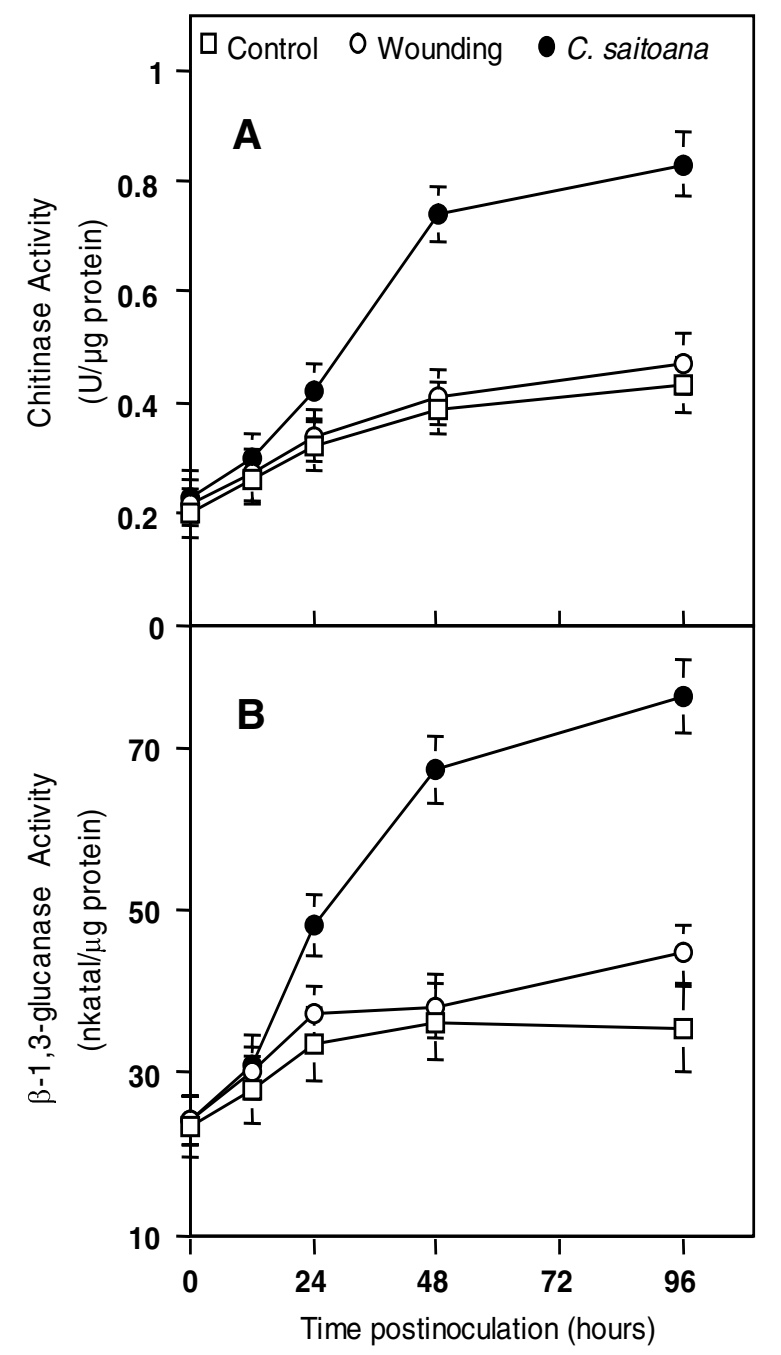

Fig. 4. Time course of changes in $\mathbf{A}$, chitinase and $\mathbf{B}, \beta-1,3$-glucanase activity in nontreated tissues close to wounds of fresh apples that have been treated with Candida saitoana $(\bullet)$ or sterile water $(O)$ and of nonwounded control fruit $(\square)$. Extracts were obtained 0, 12, 24, 48, and $96 \mathrm{~h}$ after treatment, and enzyme activities were determined. The figure is based on the data from a representative of two repeated experiments. Mean \pm SD. 
serves to maintain cellular organization, it is conceivable that their ability to synthesize defense responses would decline with the onset of ripening. This is well illustrated by the fact that the resistance of fruit and vegetables to infection declines rapidly with the onset of ripening, thus indicating that resistance to infection and ripening are inextricably linked (6). The effect of ripening on tissue responsiveness to elicitor treatment was also reported in carrot in which UV-induced resistance against $B$. cinerea and 6methoxymellen accumulations decreased with the increased physiological age of the tissue (15).

Although a causal connection between the accumulation of chitinase and $\beta$-1,3-glucanase and systemic protection has not yet been established, the occurrence of high levels of these enzymes in systemically protected tissue suggest their involvement in disease resistance. In fresh apples, the onset of the systemic resistance to $B$. cinerea closely paralleled the increase in chitinase and $\beta$-1,3-glucanase activity in systemically protected tissue. These results, which are consistent with the temporal and spatial induction of pathogenesis-related (PR) proteins and likely concomitantly with induced resistance $(8,21)$, show that apple fruit are capable of responding to microbial elicitor treatment as seen in other crops. In several plant-pathogen interactions, the induction and accumulation of PR proteins including chitinase and $\beta$-1,3-glucanase is often correlated with the onset of induced resistance (12, 17,21,22). Chitinase and $\beta$-1,3-glucanase hydrolyze fungal cell walls and in combination they have been shown to inhibit the in vitro growth of several pathogenic fungi $(18,20)$.

In conclusion, these results show that treatment of fresh apples with $C$. saitoana induced systemic resistance against $B$. cinerea that appeared to be correlated with a systemic increase in chitinase and $\beta$-1,3-glucanase activity. The observed fruit-mediated resistance induced by the microbial antagonist shows that the activation of defense mechanisms in harvested crops is feasible and has potential in reducing postharvest diseases. Considering that antagonistic yeasts are effective only when introduced into injury before or within a few hours of inoculation with the pathogen (7), the expression of disease resistance, 48 to $72 \mathrm{~h}$ after yeast treatment, may not have a decisive role in local protection. This does not preclude a supporting role for induced resistance in combination with the antagonistic activity of the yeast.

\section{LITERATURE CITED}

1. Abeles, F. B., and Forrence, L. E. 1970. Temporal and hormonal control $\beta-1,3$-glucanase in Phaseolus vulgaris L. Plant Physiol. 45:395-400.

2. Arras, G. 1996. Mode of action of an isolate of Candida famata in biological control of Penicillium digitatum in orange fruits. Postharv. Biol/Technology 8:191-198.

3. Bull, C. T., Stack, J. P., and Smilanick, J. L. 1997. Pseudomonas syringae strains ESC-10 and ESC-11 survive in wounds on citrus and control green and blue molds of citrus. Biol. Control 8:81-88.

4. Chand-Goyal, T., and Spotts, R. A. 1997. Biological control of postharvest diseases of apple and pear under semi-commercial and commercial conditions using three saprophytic yeasts. Biol. Control 10:199-206.

5. Droby, S., and Chalutz, E. 1994. Mode of action of biocontrol agents for postharvest diseases. Pages 63-75 in: Biological Control of Postharvest
Diseases of Fruits and Vegetables-Theory and Practice. C. L. Wilson and M. E. Wisniewski, eds. CRC Press, Boca Raton, FL.

6. Eckert, J. W., and Raynayake, M. 1983. Host-pathogen interaction in postharvest diseases. Pages 247-260 in: Postharvest Physiology and Crop Preservation. M. Liberman, ed. Plenum Press, New York.

7. El Ghaouth, A., Wilson, C., and Wisniewski, M. 1998. Ultrastructural and cytochemical aspect of the biocontrol activity of Candida saitoana in apple fruit. Phytopathology 88:282-291.

8. Hammerschmidt, R., and Kuc, J. (eds.) 1995. Induced Resistance to Disease in Plants. Kluwer Publishers, Dordrecht, the Netherlands.

9. Ippolito, A., El Ghaouth, A., Wisniewski, M., and Wilson, C. 2000. Control of postharvest decay of apple fruit by Aureobasidium pullulans and induction of defense responses. Postharv. Biol. 19:265-272.

10. Janisiewicz, W. J. 1998. Biocontrol of postharvest diseases of temperate fruits: Challenges and opportunities. Pages 171-198 in: Plant-Microbe Interactions and Biological Control. J. Boland and L. D. Kuykendall, eds. Marcel Dekker, Inc., New York.

11. Kloepper, J. W., Tuzun, S., and Kuc, J. A. 1992. Proposed definitions related to induced disease resistance. Biocontrol Sci. Technol. 2:349-351.

12. Kuc, J., and Strobel, N. 1992. Induced resistance using pathogens and nonpathogens. Pages 295-303 in: Biological Control of Plant Diseases. E. Tjamos, G. Papavisas, and R. J. Cook, eds. Plenum Press, New York.

13. Lawton, K., Friedrich, L., Hunt, M., Weymann, K., Kessmann, H., Staub, T., and Ryals, J. 1996. Benzothiadiazole induces disease resistance in Arabidopsis by activation of the systemic acquired resistance signal transduction pathway. Plant J. 10:71-82.

14. Leeman, M., Van Pelt, J. A., Den Ouden, F. M., Heinsbroek, M., and Bakker, P. A. H. M. 1995. Induction of systemic resistance by Pseudomonas fluorescens in radish cultivars differing in susceptibility to fusarium wilt, using a novel bioassay. Eur. J. Plant Pathol. 101:655-664.

15. Mercier, J., Arul, J., Ponnampalam, R., and Boulet, M. 1993. Induction of 6-methoxymellein and resistance to storage pathogens in carrot slices by UV-C. J. Phytopathol. 137:44-55.

16. Rodov, V., Ben-Yehoshua, S., Albaglis, R., and Fang, D. 1994. Accumulation of phytoalexins scoparone and scopoletin in citrus fruits subjected to various postharvest treatments. Acta Hortic. 381:517-523.

17. Ryalls, J., Neuenschwander, U., Willits, M., Molina, A., Steiner, H. Y., and Hunt, M. 1996. Systemic acquired resistance. Plant Cell 8:18091819.

18. Schlumbaum, A., Mauch, F., Vogeli, U., and Boller, T. 1986. Plant chitinases are potent inhibitors of fungal growth. Nature 324:365-367.

19. Schroder, M., Hahlbrock, K., and Kombrink, E. 1992. Temporal and spatial patterns of $\beta$-1,3-glucanase and chitinase induction in potato leaves infected by Phytophthora infestans. Plant J. 2:161-172.

20. Sela-Buurlage, M. B., Ponstein, A. S., Bres-Vloemans, B., Melchers, L. O., Van den Elzen, P., and Cornelissen, B. J. C. 1993. Only specific tobacco chitinases and $\beta-1,3$-glucanases exhibit antifungal activity. Plant Physiol. 101:857-863.

21. Sticher, L., Mauch-Mani, B., and Metraux, J. P. 1997. Systemic acquired resistance. Annu. Rev. Phytopathol. 35:235-270.

22. Van Loon, L. C., Bakker, P. A. H. M., and Pieterse, M. J. 1998. Systemic resistance induced by rhizosphere bacteria. Annu. Rev. Phytopathol. 36:453-483.

23. Wilson, C. L., and Wisniewski, M. E. (eds.) 1994. Biological Control of Postharvest Diseases of Fruits and Vegetables-Theory and Practice. CRC Press, Boca Raton, FL.

24. Wirth, S. A., and Wolf, G. A. 1990. Dye-labelled substrates for the assay and detection of chitinase and lysozyme activity. J. Microbiol. Methods 11:197-205.

25. Wisniewski, M., Biles, C. L., Droby, S., McLaughlin, R., Wilson, C. L., and Chalutz, E. 1991. Mode of action of postharvest biocontrol yeast, Pichia guilliermondii. I. Characterization of attachment to Botrytis cinerea. Physiol. Mol. Plant Pathol. 39:245-258. 